\title{
Evaluation of Internal Control Over Financial Reporting on Inventory Management: A Case Study on Inventory Management at National Human Right Commission
}

\author{
Erfan Adrianto \\ Faculty of Economic and Business \\ Universitas Indonesia Jakarta, \\ Indonesia \\ adriantoerfan@gmail.com
}

\author{
Trisacti Wahyuni \\ Faculty of Economic and Business \\ Universitas Indonesia Jakarta, \\ Indonesia \\ trisacti_wahyuni@yahoo.com
}

\begin{abstract}
The purpose of this study is to assess the effectiveness and propose improvements on internal control over inventory management that can improve accountability of financial reporting in the National Commission on Human Rights. This research uses qualitative research methods and case study approach with the National Human Rights Commission as the unit of analysis. The results show that internal control over inventory management has not been effective. There are some risks that the controls are inadequate, which could potentially lead to material misstatement in the financial statements. This study found the storage and reporting processes in the inventory warehouse inadequate, unclear and incomplete standard operating procedures in the inventory warehouse, the Chart of Account is poorly understood and the inventory purchase document is invalid. This research suggests the creation of warehouse reporting mechanisms, hiring warehouse personnel, improvements to standard operating procedures in inventory warehouses, socializing the Chart of Account and establishing standard operating procedures for the preparation of inventory purchasing documents.
\end{abstract}

Keywords - internal control, unternal control over financial reporting, inventory

\section{INTRODUCTION}

Law Number 1 Year 2004 on State Treasury mandates the government to exercise comprehensive internal control with the aim of improving the performance, transparency and accountability of state financial management. In accordance with Government Regulation Number 60 Year 2008, government control system has a characteristic inherent in the activity and implemented by all employees continuously. The control elements set forth in these government regulations include the control environment, risk assessment, control activities, information and communication, and monitoring.

Internal control over financial reporting is conducted with the aim of providing confidence that the financial statements have been prepared with reliable and in accordance with government accounting standards. Reliable financial statements are financial statements that are free from material misstatements.
Nasional Human Rigth Commisson (KOMNAS HAM) financial statements quality has decreased. KOMNAS HAM's 2010 financial statements through 2014 have unqualified opinion. The Supreme Audit Agency (BPK), gave a disclaimer opinion on KOMNAS HAM's 2015 and 2016 Financial Statements. The BPK audit report on internal control of 2016 shows some problems. BPK does not believe in the fairness of the value of inventory on the balance sheet. The comparison of inventory expenditure in the budget realization report with the inventory purchase report on the inventory application shows a difference of $\mathrm{Rp} 118,547,758$. There is a manual journal on inventory transactions of $\mathrm{Rp}$ $273,669,092$ which is not supported by any document. There is a difference in the value of inventory expense reported in the SAIBA application and inventory application.

Internal control has a significant influence on the quality of government financial statements (Herawati, 2014) and private (Rokhlinasari and Hidayat, 2016). The higher effectiveness of internal controls, increases the assurance that financial statements are free from material misstatements. The adequacy of internal control over financial reporting will be able to reduce the risk of material misstatement in financial statements [1].

This study aims to assess effectiveness and provide suggestions for improvements to internal control over inventory management that can improve accountability of financial reporting in KOMNAS HAM. Measuring the effectiveness of internal control over inventory management needs to be done to see which control activities are weak. Proposed improvements are expected to correct those weaknesses.

\section{LITERATURE REVIEW AND HYPOTHESIS DEVELOPMENT}

\section{A. COSO Framework}

COSO's Internal Control-Integrated Framework is one of COSO's products that is a framework for designing, implementing, and running internal controls and assessing the effectiveness of internal controls. 


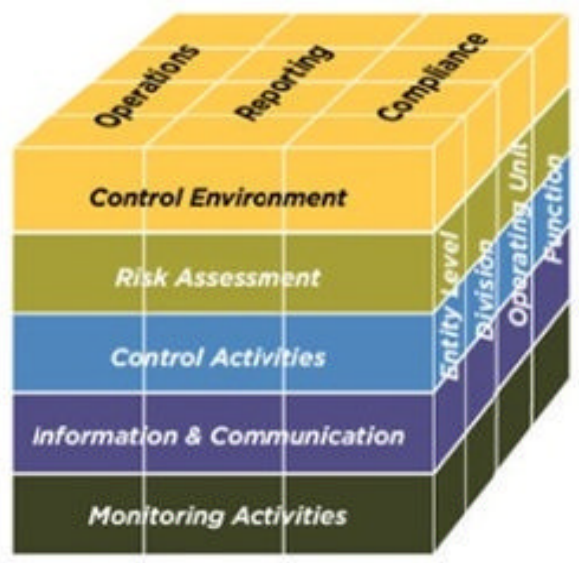

Fig. 1. The COSO Cube

According to $\mathrm{COSO}$, internal control consists of five components:

\section{Control Environment}

Control environment is a collection of standards, processes, and structures that are the basis for internal control can work well in an organization.

2. Risk Assessment

Risk assessment is a dynamic and repeatable process in analyzing and identifying organizational risks in achieving its objectives.

\section{Control Activity}

Control activities are actions undertaken through policies and procedures that can help management to control risk so that the achievement of organizational goals can be accomplished.

\section{Information and Communication}

Management can obtain quality and relevant information from internal and external sources. Management uses that information to support the functioning of internal control components. Communication enables the organization to share relevant and quality information internally and externally

\section{Monitoring Activity}

Monitoring is undertaken to ensure that the five components of the internal control function properly.

\section{B. Internal Control}

The main objectives internal control are the effectiveness and efficiency of operations, reliability of financial statements, and compliance with the laws and regulations [2]. Internal control aims to provide reasonable assurance of the effectiveness and efficiency of government goals, financial reporting reliability, asset security, and compliance with laws and regulations (Goverment of The Republic of Indonesia, 2018)

In the COSO framework, internal control is effective when able to provide reasonable assurance that the organization's objectives can be achieved. An effective internal control system is also able to reduce the risk of failure to achieve goals either related to the purpose of operations, reporting or compliance [2].

To obtain effective control, then:

a. Each component of internal control and relevant principles is manifestly established and functioning.

b. The five components of internal control work together and are integrated to reduce the risk of failure to achieve organizational goals.

According to Auditing Standard (USA) 2201 issued by PCAOB, the design of internal control is effective if it meets the following requirements:

a. Operationally, the design can be implemented.

b. Design controls can meet control objectives.

c. The design may prevent or detect errors or fraud which may cause material misstatements in financial reporting.

The design of effective internal controls ensures that any financial statement assertion is free from material misstatement. Financial Statements assertion consist of existence and occurance, valuation, completeness, right \& obligation, presentation and disclosure.

\section{Internal Control Over Financial Reporting (ICFR)}

ICFR is defined by The U.S Securities and Exchange Commission's (SEC) as follows:

"a process designed by, or under the supervision of, the [company's] principal executive and principal financial officers, or persons performing similiar functions, and effected by registrant's board of directors, management and other personnel, to provide reasonable assurance regarding the realibility of financial reporting and the preparation of financial statements for external purposes in accordance with GAPP and includes those policies and procedures that

a) Pertain to the maintenance of records that, in reasonable detail, accurately and fairly reflect the transactions and dispositons of the assets of the company;

b) Provide reasonable assurance that transactions are recorded as necessary to permit preparation of financial statements in accordance with GAPP, and the receipts and expenditures of the company are being made only in accordance with authorizations of management and directors of company; and

c) Provide reasonable assurance regarding preventions or timely detection of unauthorized acquisition, use, or disposition of the company's assets that could have a material effect on the financial statements."

The key component of ICFR is a control activity that has three concepts: task separation, prevention control and detection control

\section{a) Separation of duties and authority}

This concept involves assigning responsibility for different parts of a process to different personnel so that no single person can control the entire process. 


\section{b) Preventive Control}

Preventive control aims to prevent the occurrence of an event that is not in accordance with the purpose of control.

\section{c) Detective Control}

Detective control is intended to identify any errors or illegal activities immediately. So that correction can be done within the specified time.

ICFR operates at entity level, process/transaction level and information technology level. Entity-level controls are designed to provide reasonable assurance that goals related to the company as a whole are achieved. These controls have an overall impact on the organization's internal control system. Transaction level control is a control at the level of processes or transactions related to a single activity. Information technology level control is the design of control over the use of information technology, which including general control and application control [3].

The control self-assessment (CSA) approach is used to assess ICFR. In this approach, self-assessment is carried out by management so management is fully involved in the organizational assessment process. With this approach it is expected that the assessment process will be able to run quickly, efficiently and effectively and can provide added value for the organization because of findings and recommendations that focus on improvement [4].

Inventories are a current asset in the form of goods or equipment intended to support government operations. Included in the definition are goods intended to be sold and/or delivered in the framework of service to the public [5].

Inventory in its form can be grouped in 4 form that is:

a) Goods or supplies for government operations.

b) Goods or supplies in the production process.

c) Goods in the production process to be sold or delivered to the public.

d) Goods are kept for sale or handed over to the public.

Inventories are recognized in the financial statements when potential future economic benefits are obtained or in the event of ownership transfer. The inventory value is measured at cost, cost of goods sold or fair value [5]

Perpetual method is used to record supplies. Inventories are valued using FIFO (First In First Out) method. The inventory cost is recorded at inventory usage. The measurement of inventory usage is calculated based on physical inventory (stock opname) (Ministry of Finance of The Republic of Indonesia, 2016b).

Administration of State Property (BMN) consists of the process of bookkeeping, inventory and reporting. Bookkeeping is the registration and recording of BMN into List of Goods. Inventory is data collection, recording and reporting of BMN data collection. Reporting is an activity of preparation and delivery of data and information $\mathrm{BMN}$ [6].

\section{RESEARCH METHOD}

This research uses qualitative method and case study approach. Qualitative research is a study to explore and understand the meaning that by some individuals or groups of people ascribed to social or humanitarian problems. This study explains, describes the information that exist in the core phenomenon that occurs in participants in research with more depth to understand the meaning of a problem that exist in the object of research [7]. The case study approach is a systematic study that investigates phenomena in a real-life context, when the boundaries between phenomena and context are not visibly apparent, and where multiple sources of evidence are used [8]. This research uses one unit analysis. KOMNAS HAM was chosen because its financial report received 2 times disclamer opinion in a row.

This study uses primary data. Primary data is data that is not available publicly. Data collected using instruments:

\section{a) Interview}

Interviews were conducted to obtain primary data from participants. Susan Stainback (1988) in Sugiyono [9] argued that with the interview can be obtained more in-depth information from participants about its interpretation of the situation and the phenomenon that occurred. Interviews were conducted face-to-face by using structured interview approach. Interviews were conducted with persons responsible for inventory management.

\section{b) Observation}

Observation is a method of data collection by engaging in an activity to see what people do and describe, analyze, and interpret what has been seen [10].

\section{c) Documentation}

Yin [8] states that the use of documents as research data can add other specific details to support information from other sources. Creswell [7], explains the benefits of using documents in data collection, allowing researchers to acquire language and textual words from participants, accessible at any time, present weighted data, and as written proof so as to save time and money.

The interview result was then made a transcript. The results of the interview transcripts are then analyzed. Content Analysis will be used to process the results of the interview. Krippendorff (1980) in Yudhi [11] defines content analysis as a research technique to make valid conclusions from data obtained in accordance with the intended context. Content analysis is also described as a technique for making inferences by identifying the specific characteristics of an objective and systematic message (Holsti, 1969: in Yudhi, [11]. The results of this interview will be analyzed to obtain information on what issues are constraints related to internal control over inventories. Data analysis is done by using gap analysis to find out whether the existing conditions are in accordance with the expected.

\section{ANALYSIS AND DISCUSSION}

The analysis and discussion are conducted on the control activities in the inventory management process in mitigating the risks related to financial reporting. Based on Government Regulation No. 27 of 2014 and Regulation of the Minister of 
Finance No. 181/PMK.06/2016 the inventory management process can be divided into:
a) Procurement Process.
b) Recording Process of Inventory Purchase.
c) Storage Process.
d) Recording Process of Inventory Usage.
e) Stock Opname Process.
f) Reporting Process.

\section{A. Risk and Control on Procurement Process}

\section{1) R1. Mark-up Risk}

Accounting Standard 05 states that inventory purchases are reported at acquisition cost. The acquisition cost is the purchase price, plus any other costs that can be directly charged to the acquisition of inventory.

Procurement process with direct payment mechanism is done by preparing Self Estimate Price (HPS). HPS is compiled using 2 methods, e-catalog and market price. The Committing Officer (PPK) conducts the inventories supplier selection by using e-procurement, auction or direct appointment. HPS is used as a reference in the selection of inventories suppliers.

HPS preparation is a control activity that minimizes mark-up. The preparation of HPS provides a price transparency and specification of inventories. Price and specification of inventories in e-catalog compiled by procurement policy agency (LKPP) which is an independent institution and updated periodically. Market prices are the most reliable method of reflecting the value of inventory.

Procurement of inventory by petty cash mechanism begins with purchase orders to staff purchases by PPK. The purchasing staff makes a direct purchase to the supplier. Purchase receipts submitted to PPK for approval.

Procurement of inventories with petty cash mechanism poses a risk of mark-up. This happens because the purchasing staff is not given a price reference. Purchasing staff can cheat by providing more expensive purchase receipts. This may violate the management assertion regarding the valuation of inventories.

Control activities undertaken are PPK conducting checks of receipts. Checks are made by comparing prices between receipts and e-catalogs or suppliers that have published prices. In the event of a mark-up, the PPK returns the purchase receipt to the purchasing staff. The results of inspection in 2016 there is no mark-up of procurement inventory.

\section{2) R2. The Risk of Discrepancy between BAST and} Inventory Received

goods receipt documents (BAST) as evidence that the inventories have been received and in accordance with the contract. BAST is a document used by the Inventory Application Operator to input the acquisition of inventory.

With regard to the completeness and occurance assertion, there is a risk that the inventory value in the inventory report is not the same as the physical inventory. The process of shipping inventory is done in stages. Thus, proof of contract completion may consist of several inventory delivery documents. The Beneficiary Officer makes the BAST based on the inventory delivery document. When the inventory delivery document is not in accordance with the physical goods, then BAST becomes not the same as the physical inventory received.

Control activities carried out by checking inventory items shipped. Inventories shipped are matched with inventory delivery documents. The inventory delivery document is signed only if the quantity and quality of the inventory are in accordance with the shipping documents. The inventory delivery document is stored by the Beneficiary Officer as the source document of the BAST manufacture. This control is adequate in mitigating the risk of BAST differences with the inventory received.

\section{3) R3. The Risk of Differences Betweet BAST and} Contract

The Supplier sends inventory in accordance with the quantity and specifications of the contract. BAST is a document that states the inventory have been received and in accordance with the contract. BAST is signed by the Beneficiary officer and PPK.

Differences in inventory quantities and specifications between BAST and contracts raise the risk of differences in the value of inventory purchases in the budget and realization reports. This distinction violates the assertion of completeness and occurance. The beneficiary officer does not get a copy of the contract, so he cannot check. The beneficiary officer only checks the matches of inventory delivery documents and inventories sent.

PPK checks BAST before signing it. BAST is matched to its contract. Only BASTs that match their contracts can be paid. This control activity is adequate because it can detect BAST and contract mismatches.

\section{B. Risk and Control on Recording Process of Inventory Purchase}

\section{1) R4. Chart of Account Inaccuracy Risk}

The List of Budget Implementation (DIPA) and Activity Operational Guidance (POK) is a budget implementation document that becomes a reference in the procurement process. PPK prepares a procurement payment document that contains program code, activities and accounts in accordance with DIPA and POK. The payment document is then submitted to the Finance Department for payment processing.

There is a risk that the acquisition of inventory does not use predetermined accounts. PPK does not perform an analysis of the accuracy of accounts in DIPA and POK. PPK does not understand what account should be used. The inaccuracy of using the chart of account causes errors in the financial statements. The budget realization report cannot report the correct value. This condition violates the management's assertion regarding presentation and disclosure.

Control activities are performed by verifying the account and the type of inventory on the payment document. The account verification process is done by matching the account on the letter of payment request (SPP) with the type of goods on BAST. The verification officer prepares the approval sheet. The approval sheet is signed by the head of the 
verification and bookkeeping sub-section. Payment documents are subsequently submitted to the treasury subdivision.

The treasury subdivision shall issue a Payment Order Letter (SPM). The SPM Signatory Officer matches the account between SPM and SPP as well as supporting documents.

There is still an unexpected error of account use on SPP The audit results of the Financial Report of 2016 by the BPK found errors in the use of inventory accounts on letter of disbursement of funds (SP2D). Finance Division sends SP2D account changes to the state treasury service office (KPPN) frequently.

\section{2) R5. Risk of Input Error In SAIBA Application}

Regarding the fulfillment of the completeness assertion, there is a risk that not all SP2D are recorded and reported in the financial statements. The SP2D Recording is performed by the SAIBA Application Operator by sending the Computer Data Archive (ADK) from the SAS Application. The SP2D recording process is performed in several different and unintegrated applications. This condition raises the risk that not all SP2D are recorded and reported in the financial statements.

Reconciliation between SAIBA Application Operator and $\mathrm{KPPN}$ is done to prevent SP2D data difference. The SAIBA Application Operator is required to reconcile the realization of budget expenditures, revenues and budget ceilings every month. The budget realization data is matched with budget realization data already issued by KPPN. The matched data elements are SPM number and date, SP2D number and date, gross spend amount, total deduction, program code, activity code and account code. If all elements of the reconciliation data are the same, a Reconciliation Newsletter is issued. There is no difference in budget realization data between KOMNAS HAM financial report and budget realization report from KPPN.

\section{3) R6. Risk of Input Error In inventory Application}

With regard to the completeness and valuation assertions, there is a risk that not all purchases of inventory are recorded or recorded properly in BMN reports. Recording of inventory purchases in the accounting and reporting system of BMN (SAP-BMN) is performed using the Inventory Application. The inventory purchase record begins with the SP2D selection process. SP2D is then analyzed by staff of Equipment and Inventory Subdivision. The inventory purchasing document is then prepared. The inventory purchasing document is used as a tool to control the accuracy of inventory price calculation on SP2D. Inventory purchasing document is also used as a tool to calculate the price of each type of inventory. Inventory purchasing document are given numbers and dates. The Application Inventory operator uses the inventory purchasing document as a source document to record inventory purchases in the Inventory Application. There is a possibility that SP2D has not been made any inventory purchasing document or errors in the preparation of inventory purchasing document.

A reconciliation between the Inventory Application and the SAIBA Application is performed to detect the error and incompleteness of the inventory purchase document. The inventory purchase data recorded by the Inventory
Application Operator is matched to the inventory purchase data recorded by the SAIBA Application Operator. There is still a discrepancy between records in the Inventory Application and SAIBA Application. Manually prepared inventory purchasing document and no checking and authorization process is the cause. There is no control activity in this document-making process. The difference is also due to misuse of inventory spending accounts that cannot be detected prior to the issuance of SPM.

\section{4) Fictitious Document Risk}

With regard to occurance assertions, there is a risk that documents of inventory purchases recorded in the Inventory Application are fictitious. The Supplies and Inventory SubSection is responsible for administering and reporting on BMN. The Supplies and Inventory Sub-section also has an obligation to secure the assets acquired.

No control activities are undertaken to control the emergence of these risks. The process of recording inventory purchases using only inventory purchasing document is very risky. The inventory purchasing document is prepared using SP2D. The inventory purchasing document cannot be compared with the asset acquisition document. There are no inventory acquisition report from the all inventory warehouse. The inventory recording on the Inventory Application cannot be compared to the acquisition of inventory in the warehouse report.

\section{5) R7. Fictitious Document Risk}

With regard to occurance assertions, there is a risk that documents of inventory purchases recorded in the Inventory Application are fictitious. The Supplies and Inventory SubSection is responsible for administering and reporting on BMN. The Supplies and Inventory Sub-section also has an obligation to secure the assets acquired.

No control activities are undertaken to control the emergence of these risks. The process of recording inventory purchases using only inventory purchasing document is very risky. The inventory purchasing document is prepared using SP2D. The inventory purchasing document cannot be compared with the asset acquisition document. There are no inventory acquisition report from the all inventory warehouse. The inventory recording on the Inventory Application cannot be compared to the acquisition of inventory in the warehouse report.

6) R8. The Risk of Difference in Inventory and Delivery Documents

The inventory supplier carries the Shipping Document while delivering inventory. The Shipping Document contains a list of goods sent by the provider. The warehouse officer records the acquisition of inventory based on the shipping document.

Regarding the existence and occurance assertion, there is a risk of inaccuracy of the amount and type of inventory between shipping documents and inventories delivered. The shipping document is the source document used by the warehouse officer to record on the stock card. If the shipping document is incorrect with the inventory shipped, the stock card does not reflect the actual quantity and type of inventory in the warehouse. 
Observation shows that the warehouse officer checks every inventory that will enter the warehouse. The warehouse officer physically checks the quantity and condition of the supplies. The warehouse officer matches the shipping documents with inventory shipped.

\section{7) R9. Risk of Input Error In Stock Card}

The stock card is the only inventory control document owned by the warehouse officer. The stock card is created as many types of inventory items stored in the warehouse. The inventory recording on the stock card is done manually.

The stock card is used to record the purchase and usage of inventory from the warehouse. When the inventory is received by the warehouse officer, the warehouse officer inputs all inventory items received on each stock card. There is a risk of recording errors on the stock card because records are done manually. This risk will affect the valuation assertion.

There is no control activity to reduce the risk. Observation of the stock card found, there is no examination of inventory recording. The stock card format does not have an approval field. There is no stock card check on standard operating procedure (SOP) of inventory acquisition.

\section{Risks and Controls on Storage Process of Inventory}

\section{1) R10. Risk of Loss and Damage Inventory}

The risk of loss and damage to inventory arises because of inadequate storage and administration processes. Inventory is storage not in one warehouse. Warehouses are scattered in several places. Not all warehouses have warehouse officers. Inventories are difficult to monitor because the warehouses are scattered in several places. The Supplies and Inventory subdivision did not receive sufficient reports of inventory management from the entire warehouse.

No control activities are undertaken against this risk. There is only one warehouse officer that is the warehouse officer of the public bureau. There is no warehouse officer other than the public bureau warehouse.

\section{Risk and Control on Recording Process of Use of Inventory}

\section{1) R11. Invalid Request Form Risk}

The inventory request form is the source document for recording the inventory usage on the stock card. Inventory request form must be authorized. This is to avoid the misuse of inventory that can lead to froud. There is a risk that the inventory request form is not properly authorized. An incorrectly authorized inventory request form affects valuation asersion in the financial statements.

There is no rule about authorization on inventory request. The warehouse officer only checks whether the applicant has filled out the name and signature on the inventory request form. The SOP does not clearly specify who is authorized to sign the inventory request form.

\section{2) R12. The Risk of Inventory Usage Without Inventory} Request Form

The inventory user requests the required inventory by filling out the inventory request form. The warehouse officer checks the availability of the requested inventory. The warehouse officer hands over the inventory to the inventory user and then records the use of inventory on the stock card.

There is a risk warehouse officer records the use of inventory without any inventory requst form. This condition may violate occurance assertions.

There are no adequate control activities to control this risk. Observation on stock card found, stock card never checked. Standard operating procedures do not clearly set the requirement of checking inventory use on the stock card.

\section{3) R14. Risk of Incomplete Inventory Usage Report}

Inventory storage is not done centrally. The Supplies and Inventory Subdivision did not get the inventory usage report from the entire warehouse. Inventory usage reporting is only obtained from the public bureau. There is a risk that not all inventory usage is recorded in the Inventory Application.

Control Activities undertaken is to prepare reports on the use of inventory using inventory purchase documents. It is assumed that all supplies purchased by other than the Public Bureau have been used. The Inventory Application uses this inventory purchasing document as a inventory usage report.

The use of inventories purchasing document as inventory usage reports is incompatible with occurance assertions. The inventory purchase document is not a legitimate inventory usage report.

4) R15. Risk of Incomplete Reporting of Inventory Sue on The Inventory Application

There are 2 document sources of inventory use, inventory use report by warehouse officer and inventory usage paper created from inventory purchase document. The inventory use report and inventory usage paper are manually recorded by Inventory Application Operator. The Inventory Application Operator uses a different input method to input both documents. The inventory use document can have the same number. There is a risk that inventory use report and inventory usage paper have not been recorded in the inventory application due to the omission of inventory application operator.

There is no adequate internal control to reduce this risk. Document numbering cannot reduce the risk of incomplete document usage of inventory recorded on inventory application.

\section{E. Risks and Controls In Stock Opname Process \\ 1) R16. Risk of Stock Opname report is Incorrect}

Stock Opname reports are generated by manually counting inventory in the warehouse. Stock Opname should be done over a scattered warehouse. The calculation process relies on the accuracy of the officers who do stock opname. This may affect the completeness assertion if not adequately controlled.

Cross check between stock opname attendants can improve the accuracy of inventory counting. Head of Equipment and Inventory Subdivision also match Stock Opname report with the result of counting inventory in warehouse. However, since the stock opname is not done on the entire warehouse, the Stock Opname report has not shown the actual inventory value. 


\section{F. Inventory Application Risk and Control}

1) R17 Tho Risk of I Inauthorizod Aross

Inventory aplication is installed on a computer that is used also for daily work. The computer is not placed in a separate room. This condition poses a risk that the Application Inventory can be accessed by unauthorized persons.

The Inventory Application user must have a user and password. There are 2 staff who have access to the Inventory Application. Each has its own user and password. Users and passwords are never notified to others. This control is sufficient to reduce the risk of Inventory Application being accessed by unauthorized persons.

\section{2) R18. Risk of Inventory Application Damage}

Damage to the Inventory Application database results in loss of data relating to the acquisition, use, change of conditions and correction of inventory. Computers used to operate inventory applications are connected to the Internet network. This poses a database risk and Inventory Application can be damaged.

Backup of Inventory Application database is done periodically. The database backup is stored on the computer and external hard drive. Inventory Application database has never been damaged.

\section{G. Risk and Control of Ending Inventory Balance}

1) R19. The Risk of Ending Inventory Balance Difference Between SAPK and SAP-BMN

The final balance of inventories is recorded in accounting system of financial reporting (SAPK) and SAP-BMN. The final balance of inventories in SAPK and SAP-BMN should show the same number. A reconciliation between SAPK and SAP-BMN was performed before the audited financial statements were made. There is no documentation for the reconciliation. The final balance of inventories in SAPK and SAP-BMN in 2016 is the same.

Evaluation of the Effectiveness of Internal Control on Inventory Management.

Regulation of the Minister of Finance No. 14/PMK.09/2017 stipulates that ministries/agencies should conduct an assessment of the internal control over financial statements by the CSA method. KOMNAS HAM has never conducted such an assessment. There are 10 risks and inadequate controls that could potentially cause material misstatement in its financial statements. Based on the requirements of the effectiveness of control decisions according to Auditing Standard 2201, the current control design cannot meet the three required elements.

\section{CONCLUSION}

This study shows that internal control over inventory management has not been effective. There are 10 risks that have not been well-mitigated due to inadequate control activities undertaken. This condition can lead to potential misstatements in the financial statements. The causes of not yet well-mitigated risks are:

\section{Inadequate inventory management in the warehouse}

The absence of adequate inventory management in the warehouse, causing 5 risks whose control activities are inadequate. The risks are R10, R14, R15, R16 and R17. The Supplies and Inventory subdivision cannot obtain reports on the acquisition and use of inventory from the entire warehouse. Not all warehouses have officers responsible for recording, storing and reporting inventory. The Supplies and Inventory subdivision has no control over the security of all inventories in the absence of responsible officers in all warehouses. The report of ending inventory balances, inventory acquisition and inventory use reported by the Supplies and Inventory Subdivision are not reliable. The report is incomplete and cannot be trusted for it.

2. Unclear standard operating procedure of recording the use of inventory in the warehouse

The source document of the use of the inventory is a document that must go through the authorization process. The use of inventory is the use of resources owned by KOMNAS HAM. It should be clear who is responsible for the use of the inventory. The lack of authorization on the inventory demand form will allow for theft, waste and misuse of supplies. There should be a clear appointment of who will sign the goods request form which is the source document for the use of the inventory. Unclear standard operating procedures for recording of inventory usage, weakening control activities to control risk R11 and R12.

\section{Lack understanding of Chart Of Account}

Understanding of Chart of Account must be owned by all inventory managers from the planning and budgeting, procurement, storage, recording and reporting sections. The planning and budgeting section should be appropriate in determining the inventory accounts to be used in the DIPA and operational instructions. The planning and budgeting sections should also precisely place the inventory accounts for each bureau. PPK in preparing the procurement document should also consider the match between the account used and the type of goods to be purchased. The mismatch between Chart Of Account and the type of goods purchased will cause the inaccuracy of recording results between SAPK and SAP-BMN. The compilers of the financial statements should be able to analyze the linkages between all financial statements. Any accounts affected by procurement, purchasing, record keeping, storage and inventory transactions must be analyzed, so the possibility of material misstatement in the financial statements can be avoided. lack of understanding of BAS, causing internal control over R4 risk to be inadequate.

4. Purchasing inventory documents done manually and no control activities, so purchase documents become invalid

The inventory purchase document is a document that will be used to record the acquisition of inventories in the Inventory Application. There are still many errors in using inventory accounts in the procurement documents. this document is one of the mechanisms to detect it. The inability of the inventory purchase document to detect an account 
usage error will result in a difference in the inventory records in the Inventory Application with the stock card. However, this requirement faces constraints in the form of making inventory paper work purchases done manually. The making of this document has no control process because nobody checks and gives validation. For that there needs to be a control mechanism that will be able to maintain the accuracy of inventory purchase documents. R6 is a risk that its control becomes inadequate because of this condition.

5. Incompleteness standard operating procedure of recording inventory purchases in the warehouse

All incoming and outgoing warehouse transactions must be recorded on the stock card. checks on stock card recording are done on all transactions. No checking and validation of inventory recording on the stock card may result in errors of the warehouse officer in checking inventory availability. the procedure of recording inventory purchases in the stock card, not listed in the current SOP. This can result in an error in approving the inventory request. Additionally, an error in reading the availability of inventory can also result in an error in calculating the need for procurement of inventory. Internal control over R9 risk becomes inadequate due to the absence of recording inventory purchases in the stock card.

Based on the analysis of the causes of the ineffectiveness of internal control over inventory management, this study proposes:

1. Appointment of officers and the preparation of technical guidelines for inventory management for all warehouses. Immediately appointed officers in all warehouses. The warehouse officer will be a Representative of Equipment and Inventory Subdivision to carry out inventory management. It is necessary to train each new warehouse officer in order to have knowledge and skill in managing the inventory. It is also necessary to make technical guidelines for inventory management in the warehouse. In the technical guidance described how the warehouse accountability report. It also describes the format, type and reporting period that the warehouse officer must submit to the Supplies and Inventory sub-section.

2. Improvement of standard operating procedure of recording of inventory usage in the warehouse. The researcher proposes the officials signing the inventory request form to be officials at their respective bureaus. This is to better maintain the validity of the inventory request form but does not hamper the process of delivering inventory from the warehouse.

3. Socialization of Chart of Account to all inventory managers. Socialization is done not only for staff level but also needs to be done up to managerial level. This is done to equalize the understanding of all stakeholders in KOMNAS HAM.

4. Establishment of Standard Operating Procedures for Preparation of Inventory Purchase Documents. This SOP is expected to reduce the inaccuracies of the inventory purchasing paper resulting from the uniformity of the drafting process. With this SOP the control process can be implemented by entering the checking and authentication process.

5. Improvement of standard operating procedure of Recording of Inventory Purchase at warehouse. Recording the purchase of inventory in the stock card is a procedure that must exist in the SOP.

\section{LIMITATIONS AND SUGGESTION}

This research has limitations because the object of research used only on inventory management conducted in Head Office. This research also focuses only on the internal control of the transaction/process level.

Further research can be done by incorporating internal control of inventory management in representative offices and National Women's Commission (KOMNAS PEREMPUAN) as the object of research. Assessing the effectiveness of entity-level internal controls is also recommended

\section{REFERENCES}

[1] Asrulsani, M. (2017). Evaluation of Internal Control Over Financial Reporting on Tax Due Management: A Case Study On The Tax Duty Management Cycle At the Directorate General of Taxes. Master of Accounting Thesis. University of Indonesia; Jakarta.P.

[2] Committes Of Sponsoring Organizations of the Treadway Commissions. (2013). Internal Control-Integrated Framework: Executive Summary. https://www.coso.org/Documents/990025PExecutive-Summary-final-may20.pdf.

[3] Center for Audit Quality. (2013). Guide to Internal Control Over Financial Reporting. Available from : http://thecaq.org/guideinternal-control-over-financial-reporting.

[4] Kementerian Keuangan Republik Indonesia. (2017). Peraturan Menteri Keuangan Nomor 14/PMK.09/2017 Tentang Pedoman Penerapan, Penilaian dan Reviu Pengendalian Internal Atas Laporan Keuanga Pemerintah Pusat.

[5] Pemerintah Republik Indonesia. (2010). Peraturan Pemerintah Nomor 71 Tahun 2010 Tentang Standar Akuntansi Pemerintah.

[6] Kementerian Keuangan Republik Indonesia. (2016a). Peraturan Menteri Keuangan Nomor 181/PMK.06/2016 Tentang Panatausahaan Barang Milik Negara.

[7] reswell, J.W. (2014). Research Design : Qualitative, Quantitative, and Mixed Methods Approaches, $4^{\text {th }}$ Ed. California : Sage Publications, Inc.

[8] Yin, R.K. (2009).Case Study Research : Design and Methods Fourth Edition.Thousand Oaks : Sage Publication.

[9] Sugiyono.(2014).Memahami Penelitian Kualitatif. Bandung Alfabeta.

[10] Sekaran, Uma dan Roger Bougie. (2013). Research Methods for Business : A Skill Building Approach - 6th ed. United Kingdom : Jhon Wiley \& Sons Ltd.

[11] Yudhi, Purnama.(2016).Evaluation of Accountability Process Reporting of Grant Funds at Non-Profit Organizations Internalational Case Study on XYZ Organizations. Master of Accounting Thesis. University of Indonesia; Jakarta. 